\title{
Peningkatan Motivasi Komunikasi Oral bagi Siswa SLB Tunarungu dengan Ruang Kelas Berkonsep Tipografi Interaktif \& Natural
}

\author{
Talita Rahmanea dan Lea Kristina Anggraeni \\ Departemen Desain Interior, Fakultas Arsitektur Desain dan Perencanaan, \\ Institut Teknologi Sepuluh Nopember (ITS) \\ e-mail: talita14@mhs.interior.its.ac.id
}

\begin{abstract}
Abstrak - Pendidikan luar biasa di Indonesia bagi penyandang difabelitas merupakan sebuah kebutuhan yang krusial. Anak berkebutuhan khusus (ABK) mendapat pendidikan berupa Pendidikan Luar Biasa dengan bentuk sarana Sekolah Luar Biasa. Bagi Sekolah Luar Biasa khusus tunarungu, secara umum menekankan kebutuhan dari siswanya untuk dapat berkomunikasi, terutama secara oral melalui kurikulum pendidikan dan sistem pembelajaran yang menunjang, sedangkan secara infrastruktur bangunan mayoritas masih belum mendukung kebutuhan tersebut. Redesain interior ruang kelas siswa dirasa perlu guna menambahkan semangat belajar komunikasi oral siswa, terutama dalam ruang kelas yang digunakan sehari-hari. SLB-B Karya Mulia Surabaya merupakan salah satu sekolah luar biasa khusus tunarungu yang menyediakan empat jenjang sekaligus serta menawarkan fasilitas untuk umum di Surabaya. Selain memberikan pelayanan dalam pendidikan dari jenjang TKLB hingga SMALB, SLB-B Karya Mulia Surabaya juga memiliki pelayanan terapi. Dalam tahap pembelajaran komunikasi, jenjang usia yang sesuai dan paling efektif adalah sejak dini, terutama ketika menginjakkan kaki di jenjang sekolah dasar. Pengembangan desain interior ruang kelas SDLB-B Karya Mulia Surabaya menggunakan konsep tipografi interaktif natural yang memperhatikan unsur alam yang ada pada lingkungan sekitar anak dan unsur tipografi yang dikemas dalam bentuk interaktif sebagai bagian dari media edukasi penyandang tunarungu. Perencanaan desain ruang kelas mengutamakan unsur warna yang bersifat terapis, penggunaan material alam seperti kayu yang memberikan kesan relaksasi, serta penggunaan tipografi pada mural dinding dan bentukan elemen estetis. Penerapan konsep interaktif natural tipografi pada desain interior ruang kelas SDLB-B Karya Mulia Surabaya diharapkan dapat meningkatkan keterampilan siswa-siswi tunarungu dalam berkomunikasi secara oral dan mampu utnuk berkomunikasi dengan masyarakat di sekitarnya.
\end{abstract}

Kata Kunci- desain interior, interaktif, natural, SDLB-B karya mulia surabaya, tipografi, tunarungu.

\section{PENDAHULUAN}

$\mathrm{P}$ ENDIDIKAN merupakan kebutuhan utama dalam membentuk sumber daya manusia yang bermutu di Indonesia. Bangsa Indonesia terdiri dari masyarakat dengan keadaan mental dan fisik yang beragam. Bagi anak dengan keadaan mental maupun fisik yang berbeda, pemerintah menggolongkan ke dalam Anak Berkebutuhan Khusus (ABK).
Di Indonesia, berdasarkan data yang diperoleh dari Infodatin Kemenkes RI berdasarkan Susenas 2012, diketahui bahwa jumlah penyandang mencapai 2,45\% dari keseluruhan populasi penduduk anak Indonesia merupakan ABK. Jawa Timur menempati urutan kedua dari lima besar provinsi dengan jumlah ABK terbanyak, dan menempati urutan pertama dari provinsi dengan $\mathrm{ABK}$ penyandang tunarungu terbanyak di Indonesia.

Seiring perkembangan usia, anak tunarungu akan mengalami masalah dalam menghadapi budaya mendengar karena keterbatasan mereka dalam bahasa dan kemampuan mendengar. Pada usia 6 tahun keatas, usia memasuki sekolah dasar (SD), merupakan usia dimana secara karakteristik anak cenderung mulai memahami tentang lingkungan sekitar namun merasa bahwa sudut pandangnya sendiri adalah satu-satunya yang mungkin [1], sehingga menyebabkan anak tunarungu seringkali tidak memiliki keinginan serta mood untuk mempelajari komunikasi oral lebih lanjut dan diperlukannya stimulus yang mampu memberi pandangan positif dalam mempelajari komunikasi secara oral.

Secara lebih spesifik, berikut merupakan permasalahan yang mendorong perlu diterapkannya konsep ruang kelas baru adalah:

1. Bagaimana membentuk suasana kelas yang dapat menambah daya tarik minat siswa untuk lebih giat dalam belajar berbahasa secara oral?

2. Bagaimana menciptakan dan membangkitkan minat yang dapat menunjang aktifitas edukasi dan menciptakan motivasi dalam kelas?

Berdasarkan masalah di atas, maka dapat dirumuskan tujuan dari penelitian ini, yaitu:

1. Menerapkan konsep interior yang dapat menampilkan kualitas dan karakter sesuai dengan fungsi serta kebutuhan dari siswa tunarungu.

2. Menerapkan konsep interior yang mampu menciptakan suasana interior yang dapat menunjang keinginan edukasi siswa tunarungu untuk dapat aktif dalam berkomunikasi secara oral.

Menerapkan konsep interior yang mampu menumbuhkan rasa memiliki serta rasa bangga bagi pengguna kelas terhadap hasil desain yang khusus dari yang lain. 


\section{KAJIAN LITERATUR}

\section{A. Kajian Tunarungu}

Tunarungu merupakan keadaan dimana seseorang mengalami kehilangan fungsi pendengaran akibat terdapat masalah dalam sistem indera pendengarannya. Secara fisik keseluruhan, penyandang tunarungu memiliki kondisi yang sama seperti anak normal pada umumnya, namun terdapat beberapa ciri-ciri yang dialami oleh anak tunarungu sebagai dampak dari

Tunarungu dapat diartikan sebagai suatu keadaan kehilangan pendengaran yang mengakibatkan seseorang tidak dapat menangkap berbagai rangsangan, terutama melalui indera pendengarannya [2]. Secara fisik, anak tunarungu memiliki kondisi yang sama seperti anak normal pada umumnya, namun terdapat beberapa ciri-ciri yang dialami oleh anak tunarungu diantaranya sering tampak bingung dan melamun, sering bersikap tak acuh, kadang bersifat agresif, perkembangan sosialnya terbelakang, keseimbangannya kurang, kepalanya sering miring, sering meminta agar orang mau mengulang kalimatnya, jika bicara sering membuat suarasuara tertentu, jika bicara sering menggunakan tangan, jika bicara sering terlalu keras atau sebaliknya, sering sangat monoton, tidak tepat dan kadang-kadang menggunakan suara hidung [3].

\section{B. Kajian Tipografi Interaktif}

Tipografi atau typography memiliki pengertian yang meliputi penataan dan pola halaman, atau setiap barang cetak, atau dalam pengertian lebih sempit hanya meliputi pemilihan, penataan, dan berbagai hal yang berhubungan dengan pengaturan baris-baris susunan huruf [4]. Dalam desain interior, tipografi sering dimanfaatkan dan merupakan salah satu bagian dari Environmental Graphic Design (EGD). Environment Graphic Design atau istilahnya Grafis Lingkungan adalah segala bentuk grafik yang ada di lingkungan, termasuk di dalamnya berupa tanda-tanda penunjuk arah, papan pengumuman, ornamen grafis pada sebuah bangunan, pelat nama di gedung-gedung, juga segala bentuk tulisan pada objek dua maupun tiga dimensi. Ruang lingkup EGD mencakup signage, wayfinding system, exhibition design, information design, pictogram juga placemaking. Sesuai dengan fungsinya, yaitu sebagai tanda, maka tipografi juga sering diaplikasikan dalam interior ruangan. Tipografi adalah salah satu sarana untuk menterjemahkan kata-kata yang terucap ke halaman yang dapat dibaca, begitu pula sebaliknya. Peran dari pada tipografi adalah untuk mengkomunikasikan ide atau informasi dari halaman tersebut ke pengamat.

Pengertian dari interaktif adalah hal yang terkait dengan komunikasi secara dua arah, saling aktif dan saling berhubungan serta mempunyai timbal balik antara satu dengan lainnya (Warsita:2008). Sedangkan menurut Macionis, 2012, interaksi merupakan proses dalam melakukan aksi serta memberikan reaksi. Interaksi yang terjadi tidak hanya terbatas pada interaksi manusia dengan manusia, namun juga dengan benda mati. Dalam hubungan antar manusia dengan benda mati, manusia memberi reaksi hasil dari aksi benda mati tersebut. Contohnya dalam penggunaan multimedia seperti tablet. Selain multimedia pun, benda mati lainnya yang dapat memberikan aksi dan informasi seperti papan tulis serta cermin yang menimbulkan reaksi bagi penggunanya.

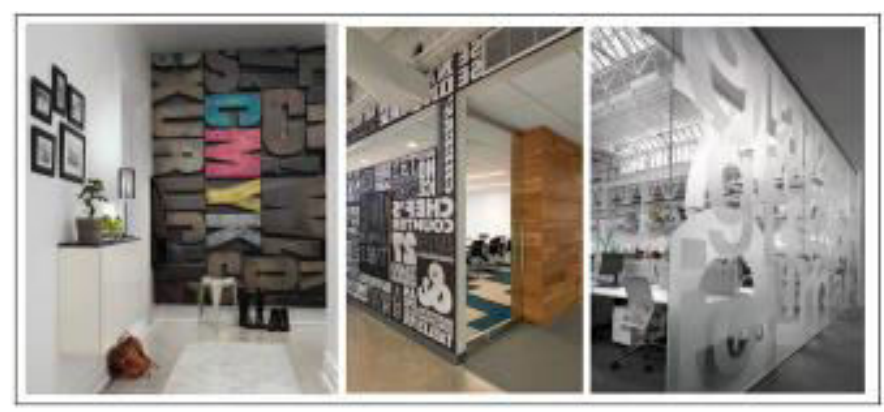

Gambar 1. Contoh aplikasi tipografi dalam interior.

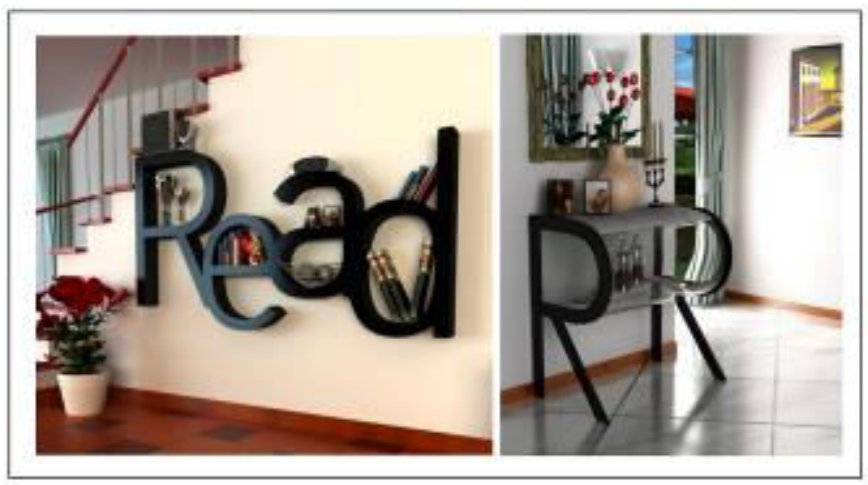

Gambar 2. Contoh aplikasi tipografi yang interaktif.

\section{Kajian Natural}

Beberapa anak yang sedang mengalami problem emosional yang sulit, termasuk bagi anak penyandang tunarungu, sering menjadi tidak bersahabat dan mengalami kesulitan untuk berinteraksi dengan orang lain maupun tugas mereka. Pada beberapa situasi atau kondisi tertentu individu tidak jarang mengalami kecemasan. Kecemasan adalah suatu keadaan yang tidak menyenangkan atau tidak nyaman pada individu yang diliputi oleh perasaan takut, khawatir, dan gelisah [5]. Cara yang paling efektif untuk membantu adalah melalui terapi dengan memanfaatkan alam.

Alam adalah salah satu unsur yang secara psikologis dapat memberikan rasa rileks dan tenang. Natural yang dimaksud merupakan natural yang merepresentasikan dan memberikan nuansa berupa alam.

\section{Ergonomi Anak}

Sekolah sebagai sarana untuk mencari ilmu dikhususkan bagi kalangan pelajar yaitu anak-anak dengan rentang usia yang menggunakan ukuran dimensi tertentu dalam mendesain.

Pada Tabel 1 [6], dijelaskan bahwa pada usia 12 tahun, anak perempuan cenderung lebih tinggi dibanding laki-laki. Anak perempuan mengalami pubertas lebih awal dari laki-laki, sehingga perkembangan fisik mereka lebih cepat dan cenderung lebih tinggi dari anak laki-laki. Selain pertumbuhan fisik, kemampuan motoric anak-anak pada usia 7-12 tahun juga semakin meningkat. Mereka semakin memiliki ketepatan 
dan kekuatan dalam berlari dan melompat. Pada beberapa anak yang tidak suka beraktifitas fisik, cenderung mengalami obesitas. Tingkat konsentrasi anak masih belum optimal, namun sudah dapat fokus pada satu aktifitas lebih dari 30 menit.

Tabel 1.

Contoh aplikasi tipografi dalam interior

\begin{tabular}{|c|c|c|c|c|c|}
\hline \multirow{3}{*}{ No } & \multirow{3}{*}{ Dimensi } & \multirow{2}{*}{\multicolumn{2}{|c|}{$\begin{array}{c}7 \text { Tahun } \\
\text { (50\%ile)-mm }\end{array}$}} & \multirow{2}{*}{\multicolumn{2}{|c|}{$\begin{array}{c}12 \text { Tahun } \\
\text { (50\%ile)-mm }\end{array}$}} \\
\hline & & & & & \\
\hline & & $\begin{array}{l}\text { Laki- } \\
\text { laki }\end{array}$ & Perempuan & $\begin{array}{l}\text { Laki- } \\
\text { laki }\end{array}$ & Perempuan \\
\hline 1 & Tinggi badan & 1230 & 1220 & 1490 & 1500 \\
\hline 2 & $\begin{array}{l}\text { Tinggi pandangan } \\
\text { mata }\end{array}$ & 1115 & 1105 & 1375 & 1385 \\
\hline 3 & $\begin{array}{l}\text { Tinggi badan saat } \\
\text { duduk }\end{array}$ & 665 & 660 & 765 & 775 \\
\hline 4 & $\begin{array}{l}\text { Tinggi pandangan } \\
\text { mata saat duduk }\end{array}$ & 550 & 555 & 650 & 665 \\
\hline
\end{tabular}

\section{URAIAN PENELITIAN}

\section{A. Proses Riset dan Teknik Pengumpulan}

Data yang digunakan untuk menguraikan masalah dan mencari solusi dari permasalahan tersebut adalah sebagai berikut:

\section{1) Studi Literatur}

Studi literatur yang dilakukan melalui pencarian data dari jurnal, buku, laporan penelirian, dan lain-lain. Data yang didapatkan adalah tinjauan tentang Sekolah Luar Biasa, gaya hidup natural, desain interior dengan tipografi, dan desain interior lainnya.

\section{2) Observasi}

Observasi yang dilakukan adalah meninjau lokasi sekolah dan mengamati segala aktivitas pada ruang kelas dan privat.

3) Wawancara

Wawancara yang dilakukan adalah untuk mencari data tentang kebutuhan pengguna kelas yang nantinya akan disesuaikan dengan konsep yang digunakan.

\section{B. Hasil Observasi}

Data yang digunakan untuk menguraikan masalah dan mencari solusi dari permasalahan tersebut adalah sebagai berikut:

1. Fasilitas yang sangat sering digunakan di kelas adalah papan tulis karena mayoritas pembelajaran dilakukan secara pasif.

2. Kualitas dari fasilitas dalam ruang kelas yang belum memadai untuk memotivasi siswa berkomunikasi.

3. Ruangan kelas dengan fasilitas lengkap dan desain interior yang fungsional memotivasi siswa untuk berkomunikasi.

\section{Hasil Wawancara}

Wawancara dilakukan dengan guru kelas 1 dari SDLB-B Karya Mulia Surabaya dengan mempertimbangkan kebutuhan siswa dalam pembelajaran serta tujuan yang ingin dicapai dari sekolah dapat dilihat pada Tabel 2.
Tabel 2.

Rangkuman hasil wawancara

\begin{tabular}{|c|c|c|}
\hline No & Pertanyaan & Jawaban \\
\hline 1 & $\begin{array}{l}\text { Bagaimana keadaan } \\
\text { kelas saat ini ? } \\
\text { (fasilitas) }\end{array}$ & $\begin{array}{l}\text { Selama ini kelas dapat digunakan } \\
\text { dengan baik, namun memang belum } \\
\text { maksimal. Untuk fasilitas, kami } \\
\text { mendapat batuan dari tahun ke } \\
\text { tahun. Namun tentu masih banyak } \\
\text { kebutuhan lainnya. Terutama dalam } \\
\text { fasilitas pembelajaran }\end{array}$ \\
\hline 2 & $\begin{array}{l}\text { Apakah kekurangan } \\
\text { tersebut mengganggu } \\
\text { aktivitas dan fungsi } \\
\text { utama kelas? }\end{array}$ & $\begin{array}{l}\text { Lumayan, karena pada era yang } \\
\text { serba modern ini pembelajaran } \\
\text { seringkali dibutuhkan sesuatu yang } \\
\text { baru dan menarik agar tidak } \\
\text { monoton dan bosan. Sedangkan } \\
\text { untuk fasilitas yang diperlukan } \\
\text { seperti LCD dan proyektor untuk } \\
\text { pembelajaran interaktif dibutuhkan }\end{array}$ \\
\hline 3 & $\begin{array}{l}\text { Apa yang menjadi } \\
\text { harapan akan } \\
\text { kelebihan dan daya } \\
\text { tarik utama dari kelas- } \\
\text { kelas yang ada di } \\
\text { SDLB karya mulia ini } \\
\text { ? }\end{array}$ & $\begin{array}{l}\text { Kelas disini menerima murid dengan } \\
\text { jumlah maksimal } 10 \text { siswa per kelas, } \\
\text { jauh lebih banyak dibanding yang } \\
\text { sudah ditentukan oleh pemerintah. } \\
\text { Namun dengan jumlah siswa yang } \\
\text { banyak tersebut siswa dapat } \\
\text { berkomunikasi antar satu dengan } \\
\text { yang lainnya secara lebih dekat dan } \\
\text { menjadi nilai tambah dalam } \\
\text { menanamkan ilmu sosial. } \\
\text { Harapannya kelas-kelas dapat } \\
\text { memfasilitasi siswa-siswa untuk } \\
\text { lebih aktif dan lebih bermotivasi } \\
\text { dalam belajar }\end{array}$ \\
\hline 4 & $\begin{array}{l}\text { Bagaimanakah } \\
\text { keinginan serta tujuan } \\
\text { anda kedepannya } \\
\text { untuk kelas-kelas ini? }\end{array}$ & $\begin{array}{l}\text { Saya hanya ingin kelas ini menjadi } \\
\text { lebih menarik, terutama tidak hanya } \\
\text { dimata orang tua saja namun juga } \\
\text { dimata murid. Agar dalam belajar } \\
\text { tidak membosankan dan } \\
\text { menyenangkan. Serta tentunya agar } \\
\text { SDLB-B Karya Mulia tetap dapat } \\
\text { menyandang statusnya sebagai } \\
\text { sekolah tuna rungu terbesar di } \\
\text { Surabaya dengan fasilitas yang } \\
\text { lengakp dan memadai. }\end{array}$ \\
\hline
\end{tabular}

\section{APLIKASI KONSEP}

\section{A. Layout Ruang Kelas}

Fungsi ruang kelas adalah sebagai pusat kegiatan edukasi pada sekolah untuk melaksanakan kegiatan belajar mengajar. Dengan luas yang cukup sempit jika dibandingkan dengan ruangan kelas dari tempat lain, ruang ini harus dapat menampung jumlah siswa yang telah ditetapkan oleh pihak sekolah yaitu sebanyak 8 orang maksimal. Ruang kelas memiliki dimensi kurang lebih $23,2 \mathrm{~m}^{2}$. Selain itu kegiatan yang dilakukan berupa kerja praktek, belajar mengajar, bermain sambil belajar, dan berkelompok.

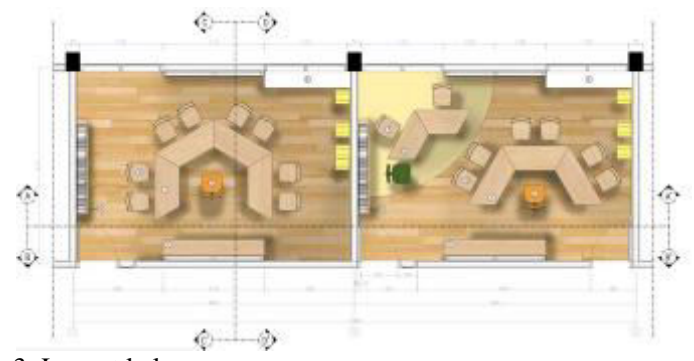

Gambar 3. Layout kelas. 
Penataan layout menyerupai bentuk hexagonal lebah. Bentuk tersebut dipilih karena fleksibel untuk digunakan dengan beberapa susunan yang berbeda, hal ini sesuai dengan kebutuhan dari ruang kelas yaitu sebagai tempat kegiatan belajar mengajar dengan berbagai bentuk pendekatan seperti berkelompok maupun berdiskusi. Kegiatan belajar mengajar dilaksanakan pada pagi hingga siang hari sehingga penggunaan cahaya mayoritas berasal dari alam.

\section{B. Penerapan Konsep Natural}

Konsep natural adalah salah satu unsur yang secara psikologis dapat memberikan rasa rileks dan tenang. Unsurunsur alam seperti air, tanah, udara, tanah, vegetasi, batubatuan juga memiliki kekayaan akan warna, suara, tekstur dan aroma, dimana hal-hal tersebut baik bagi terapi anak. Unsurunsur alam dalam lingkungan itu sendiri banyak menawarkan pilihan dan menarik perhatian anak-anak untuk bermain, berkreasi dan mencari hal-hal baru yang terjadi pada alam sekitarnya. Wawsasan dan kreativitas mereka tentang hal baru tersebut dapat tergali melalui kegiatan eksperimen, eksplorasi dari hasil pengamatan di lingkungan. Desain natural adalah desain yang diciptakan untuk mengakomodasi kebutuhan manusia akan hal-hal yang bersifat terapis. Sehingga secara garis besar keseluruhan dari redesain interior ini menggunakan konsep natural.

Sekolah luar biasa tersebut dibuat dengan tujuan untuk mengedukasi siswa terutama dalam berbahasa. Dengan siswa yang menyandang tuna rungu, maka diperlukan desain khusus yang mempermudah para siswa untuk beraktivitas dan tidak menghambat. Siswa tuna rungu cenderung sulit untuk mengidentifikasi sekitar, terutama pada area yang tidak terlihat oleh mata.

Berdasarkan karakter dari subjek pengguna sekolah yaitu siswa penyandang tuna rungu, maka desain natural dibutuhkan untuk menciptakan suasana sekolah yang nyaman tapi juga aman untuk beraktivitas dan tidak mencelakakan penggunanya. Desain natural dipercaya dapat memberi keamanan dan kenyamanan bagi siswa karena sifat alami yang dibawanya sehingga dapat memberi terapi bagi anak secara tidak langsung.

Secara keseluruhan, berikut karakteristik dari konsep desain natural yang diterapkan pada desain sekolah:

1. Pemilihan warna cenderung mendekati warna-warna natural seperti hijau, kuning, dan jingga sesuai dengan kebutuhan dan serta karakteristik dari pengguna yang ingin dikembangkan.

2. Penggunaan pencahayaan alami dimaksimalkan dengan pengaplikasian jendela yang lebar.

3. Penggunaan material berupa material kayu yang tidak berat dan memberi kesan natural.

\section{Penerapan Konsep Tipografi-Interaktif}

Unsur desain tipografi diterapkan dengan menonjolkan unsur bahasa dan kata-kata melalui huruf sebagai elemen utama desain dapat menunjang serta meningkatkan suasana berbahasa yang baik dan lebih menyenangkan. Desain tipografi yang diterapkan adalah berupa dekorasi, signage dan media edukasi. Selain itu beberapa furniture menggunakan bentukan yang berasal dari tipografi. Bentuk furnitur sangat beragam dan mencakup semua barang seperti kursi, meja, dan lemari. Unsur tipografi dapat diaplikasikan kedalam bentukan furnitur untuk mempermudah serta memaksimalkan potensi siswa-siswi tunarungu dalam berbicara secara oral melalui penggunaan dari elemen interior dengan bentuk tipografi.

Salah satu bentuk konsep tipografi yang dapat menunjang pembelajaran komunikasi secara oral maupun pembelajaran secara umum bagi siswa tunarungu adalah dengan menulis slogan pada dinding. Pada area ruang kelas, setiap kelas memiliki slogan dengan kata kunci yang berbeda. Slogan yang menjadi pilihan pun bertujuan untuk membangun karakteristik tersebut bagi siswanya dapat dilihat pada Tabel 3 .

Tabel 3.

Slogan ruang kelas

\begin{tabular}{|c|c|c|}
\hline No & $\begin{array}{c}\text { Kata Kunci } \\
\text { Slogan }\end{array}$ & Tujuan \\
\hline 1 & Pandai & $\begin{array}{l}\text { Menanamkan pengertian bahwa menjadi } \\
\text { pandai merupakan salah satu bagian dari } \\
\text { aspek kehidupan yang penting untuk } \\
\text { dimiliki }\end{array}$ \\
\hline 2 & Impian & $\begin{array}{l}\text { Menanamkan bahwa memiliki impian itu } \\
\text { penting dan dapat membentuk masa depan } \\
\text { kelak }\end{array}$ \\
\hline 3 & Sukses & $\begin{array}{l}\text { Menanamkan bahwa kesuksesan dapat } \\
\text { diraih dengan usaha yang sungguh-sungguh }\end{array}$ \\
\hline 4 & Berani & $\begin{array}{l}\text { Menanamkan keberanian dalam diri siswa } \\
\text { untuk menghadapi lingkungan kelak }\end{array}$ \\
\hline 5 & Pendidikan & $\begin{array}{l}\text { Menyadarkan pentingnya pendidikan agar } \\
\text { tetap bersemangat dalam mencari ilmu } \\
\text { untuk kedepannya }\end{array}$ \\
\hline 6 & Masa Depan & $\begin{array}{l}\text { Mulai memberi pandangan akan bagaimana } \\
\text { ke depan serta mulai memberi arahan akan } \\
\text { rencana di masa mendatang }\end{array}$ \\
\hline
\end{tabular}

Gambar 4. Tipografi interaktif multifungsi.

Slogan dalam tiap kelas dapat diatur dan diubah secara interaktif, sedangkan kata kunci tersebut akan permanen berada di kelas tersebut dan menjadi sebuah konsep yang mampu mengedukasi siswa. Pada pengaturan slogan, siswa mendapat kesempatan untuk mengubah slogan sesuai dengan kata kunci pada tiap kelas. Seperti contoh apabila pad kelas 1, kata kunci slogan merupakan "pandai" sehingga slogan yang mungkin untuk dibuat dapat berupa "Rajin pangkal pandai" atau "Belajar adalah kunci pandai". Slogan tersebut bersifat dinamis dan dihasilkan oleh hasil pemikiran siswa sehingga memicu siswa untuk berpikir secara kreatif. Desain interaktif lainnya seperti pada papan pengumuman dimana anak dapat membaca serta menempelkan karya secara aktif, serta cermin yang dapat digunakan pula sebagai media pembelajaran secara interaktif. 


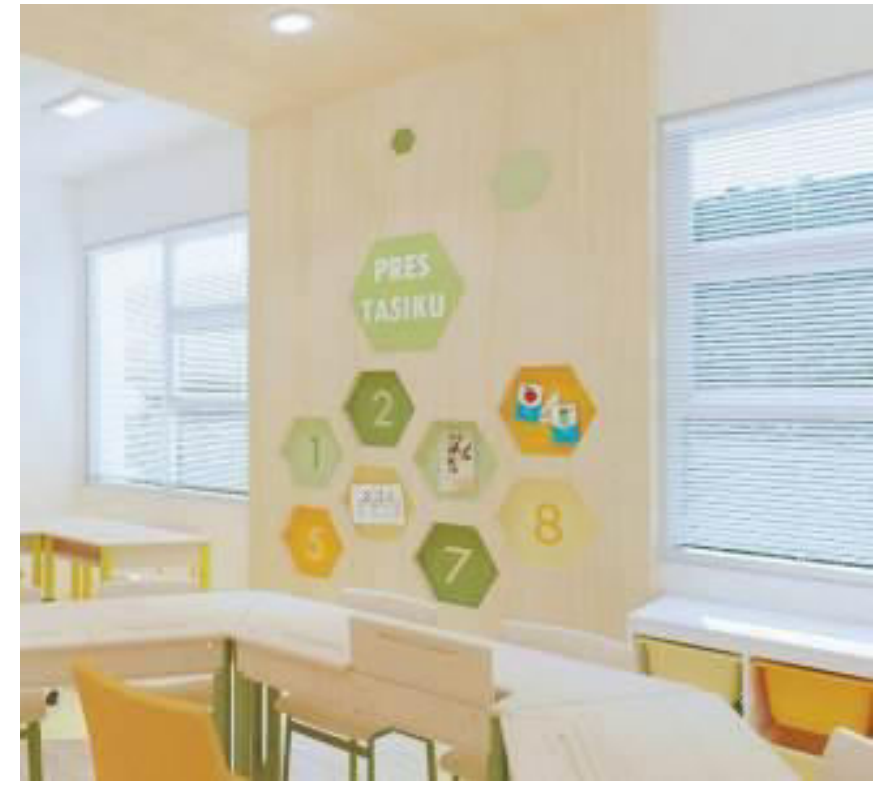

Gambar 5. Papan prestasi interaktif.

\section{Desain Akhir}

Desain utama menggunakan warna yang cerah agar ruang kelas tampak lebih luas dari seharusnya. Kemudian diberikan drop ceiling pada bagian tengah sebagai penanda untuk menciptakan kesan bahwa pusat kegiatan dilakukan di tengah. Bagi anak tunarungu, dengan adanya drop ceiling tersebut memberi kesan seperti berada dalam satu atap sebagai center dari ruangan. Selain itu pemilihan warna cerah sebagai elemen-elemen estetis sebagai penunjang minat belajar bagi siswa.

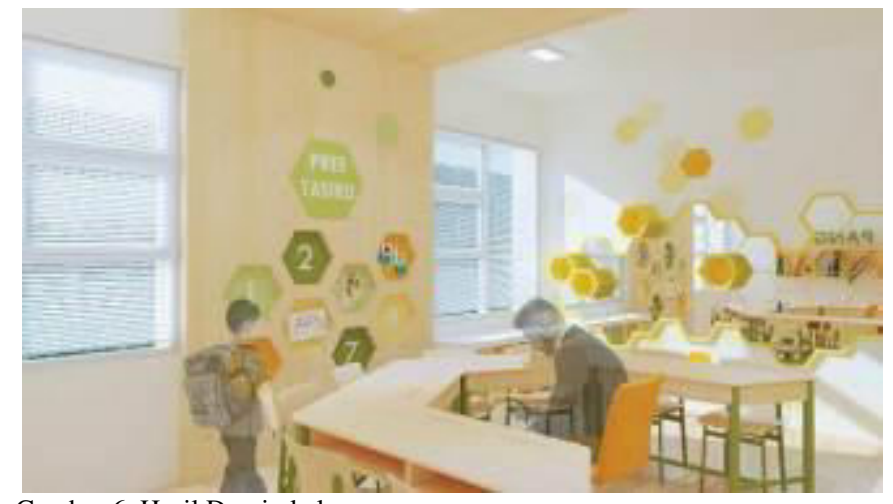

Gambar 6. Hasil Desain kelas.

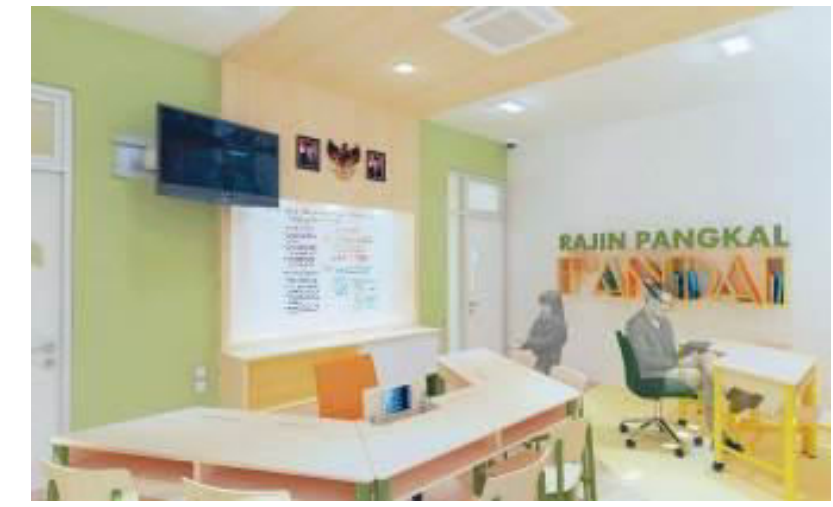

Gambar 7. Hasil Desain kelas.
Bagian depan ruangan menggunakan cat dengan warna hijau sebagai relaksasi, serta sebagai bagian yang paling menonjol dalam ruangan. Hal ini bertujuan agar siswa memberi fokusnya pada bagian depan kelas agar melihat kearah papan tulis dan tidak terdistraksi dengan bagian lain. Furnitur yang digunakan bersifat interaktif dengan adanya laci khusus multimedia pada bagian depan meja, serta rak buku berbentuk tipografi yang interaktif dan menarik.

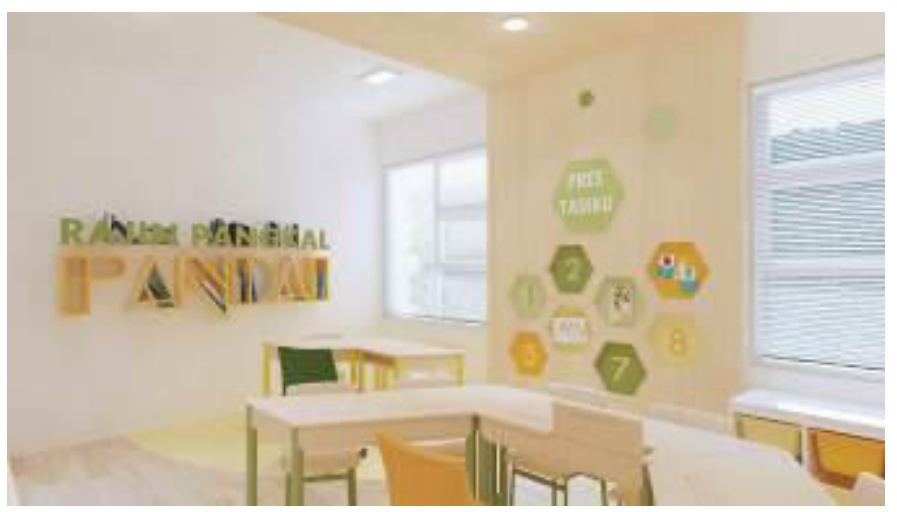

Gambar 8. Hasil Desain kelas.

\section{KESIMPULAN DAN SARAN}

\section{A. Kesimpulan}

Berdasarkan pembahasan mengenai Peningkatan Motivasi Komunikasi Oral bagi Siswa SLB Tunarungu dengan Ruang Kelas Berkonsep Tipografi Interaktif \& Natural, dapat diambil beberapa kesimpulan, yaitu:

1. Konsep natural tipografi interaktif dapat menjawab permasalahan kelas dalam sekolah luar biasa akan kebutuhan pelayanan pendidikan serta terapi yang mampu mengembangkan motivasi dan potensi siswanya dalam belajar berkomunikasi secara oral.

2. Pencapaian konsep interaktif diterapkan dalam pemilihan fungsi furnitur dan fasilitas yang mendorong minat belajar, dengan memasukkan unsur natural sebagai penunjang psikologis dan unsur tipografi dan interaktif sebagai penambah daya tarik siswa dalam mempelajari bahasa.

3. Penerapan konsep natural tipografi interaktif memungkinkan siswa untuk lebih matang berbicara secara oral sehingga dapat membantu pengembangan diri pribadi untuk dapat hidup bermasyarakat secara mandiri.

4. Dengan adanya konsep ini memungkinkan para siswa untuk lebih matang dalam berbicara terutama secara oral sehingga kelak dapat hidup mandiri dalam kehidupan bermasyarakat dengan lingkungan, seperti visi dan misi dari SLB Karya Mulia Surabaya yaitu menanamkan kreativitas dan

\section{B. Saran}

Saran yang dapat diberikan dari penelitian ini adalah memperbanyak kajian tentang perilaku pengunjung hotel bisnis dengan konsep luxury dengan variable yang berbeda 
sehingga ada banyak referensi ketika meneliti objek hotel bisnis.

\section{DAFTAR PUSTAKA}

[1] A. R. Tilley, The measure of man and woman : human factors in design. New York: Whitney Library of Design, 1993.

[2] S. Somantri, Psikologi Anak Luar Biasa. Bandung: PT. Refika Aditama, 2006.

[3] Nuraeni, Intervensi Dini Bagi Anak Bermasalah. Jakarta: Rineka Cipta,
1997.

[4] R. Brewer, An Aproach To Print A basic guide to the Printing Process. 1971.

[5] N. Harini, "Terapi Warna Untuk Mengurangi Kecemasan," Universitas Muhammadiyah Malang, 2013.

[6] L. K. Anggraeni, "Kajian Penerapan Ergonomi dalam Perancangan Bangunan Sekolah Dasar Studi Kasus SDN Bubutan IV Surabaya," Institut Teknologi Sepuluh Nopember, 2017. 